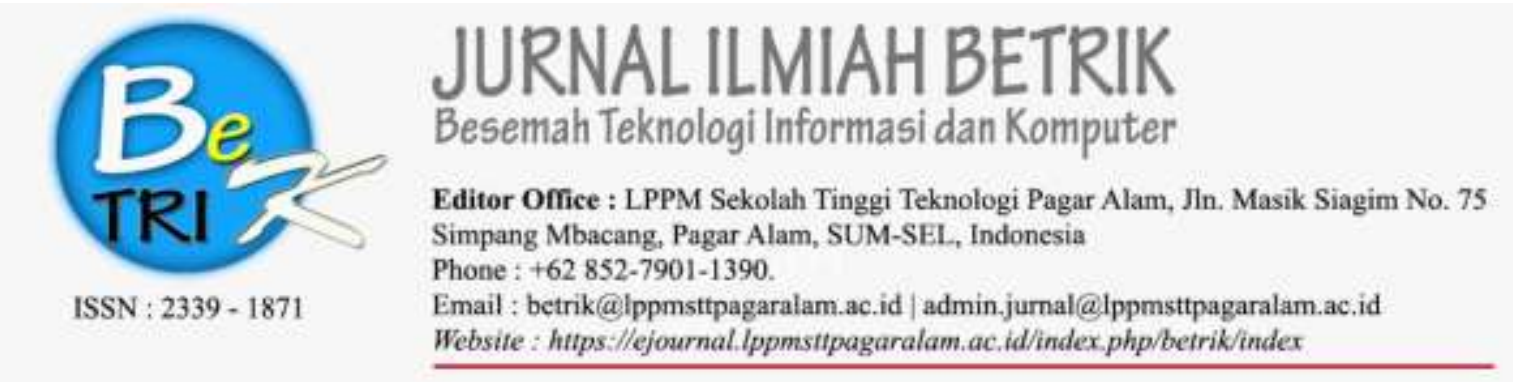

\title{
SISTEM PAKAR DIAGNOSA PENYAKIT DIABETES PADA PUSKESMAS SANDAR ANGIN KOTA PAGARALAM BERBASIS WEB
}

\author{
Idi Jangcik \\ Dosen Program Studi Sekolah Tinggi Teknologi Pagaralam \\ Jln. Masik Siagim No.01 Simpang Mbacang Dempo Tengah Pagar Alam, Kota Pagar Alam. \\ Sur-el:edijangcik@gmail.com
}

\begin{abstract}
Abstrak: Tujuan dari penelitian ini untuk memecahkan masalah yang bersifat spesifik, dalam hal ini adalah membangun sebuah sistem berbasis pengetahuan ahli dan dokter dalam mendiagnosa penyakit diabetes. Berdasarkan hasil studi pendahuluan melalui observasi dan wawancara di Puskesmas Sandar Angin Pagar Alam, bahwa fasilitas disana belum terlalu jauh menggunakan teknologi untuk mengetahui penyakit diabetes di mana seorang pasien harus mengontrol langsung ke Dokter tanpa mengetahui tandatanda atau penyebab diabetes. dari sini peneliti akan membuat sistem pakar dengan mengunakan penalaran forward chaining berbasis web dengan menggunakan pemrograman php dengan database $M y S Q L$ yang di kutip dari pakar penyakit diabetes dan buku penunjang yang berdasarkan hasil dari studi pendahuluan melalui observasi dan wawancara pada Puskesmas Sandar Angin Pagaralam. dengan mengunakan rule berdasarkan pertanyaan-pertanyaan yang mengarah kepada penyakit diabetes untuk menghasilkan sebuah keputusan dari pertanyaan yang terlewati. Sehingga menghasilkan sistem yang dapat digunakan untuk mengatasi semua persoalan yang di hadapi pasien untuk diagnosa awal dari penyakit diabetes serta untuk membantu ahli kesehatan dalam hal menyampaikan informasi tentang penyakit diabetes kepada pasien.
\end{abstract}

Kata kunci : Sistem pakar, Diabetes, Php, MySQL

\begin{abstract}
The purpose of this study to solve specific problems, in this case, is to build a knowledge-based system of experts and doctors in diagnosing diabetes. Based on the preliminary study results through observation and interviews at the Puskesmas Sandar Pagar Alam Community Center, the facilities there have not been too far using the technology to identify diabetes where a patient should control the doctor directly without knowing the signs or causes of diabetes. From here the researcher will create the expert system by using web-based forward chaining reasoning by using PHP programming with $M y S Q L$ database which quoted from diabetes expert and supporting book based on the result from preliminary study through observation and interview at Sandar Angin Pagaralam Community Health Center. By using rules based on questions that lead to diabetes to produce a decision of the question that passed. So as to produce a system that can be used to overcome all problems faced by patients for early diagnosis of diabetes and to help health professionals in delivering information about diabetes to patients.
\end{abstract}

Keywords: expert system, Diabetes, Php, MySQL 


\section{PENDAHULUAN}

Dengan kemajuan teknogi saat ini semakin pesat dan maju hal ini sangat penting bagi perkembangan sumber daya manusia. maka semakin memudahkan manusia dalam melaksanakan tugas-tugas penerapan teknologi saat ini semakin tinggi baik individu, perkantoran, dunia kesehatan maupun instansi lainnya. Peran komputer menjadi lebih meluas tidak hanya menjadi alat bantu hitung seperti penggunaan awal komputer tetapi juga sebagai alat bantu penyelesaian masalah-masalah yang di hadapi oleh manusia.

Cabang ilmu komputer yang banyak di manfaatkan oleh manusia untuk membantu kerja sistem pakar merupakan salah satu sub bidang ilmu kecerdasan buatan. Kecerdasan buatan adalah kegiatan menyediakan mesin seperti komputer dengan kemampuan menampilkan perilaku yang di anggap cerdas jika di amati oleh manusia. Ilmu seorang pakar dapat disimpan dan diaplikasikan ke dalam komputer kemudian di terapkan oleh orang lain saat di butuhkan. Dengan implemtasi sistem pakar ke dalam komputer dapat menghasilkan beberapa manfaat seperti keakurasian, kecepatan dan dapat di akses kapan pun sehingga dapat meringankan tugas dari para pakar sehingga seorang pakar tidak harus terjun langsung ke lapangan untuk memberikan informasi.

Pemanfaatan sistem pakar dalam bidang kesehatan khususnya penyakit diabetes, sistem pakar pada dunia kedokteran dapat berupa diagnosa Penyakit pada manusia, konsultasi penjagaan kesehatan manusia sampai pemberian saran penentuan solusi dari hasil diagnosa yang ada, dengan adanya sistem pakar ini di harapkan dapat memudahkan semua orang mendapatkan informasi tanpa harus datang kedinas kesehatan yang ada.

$$
\text { Dalam penelitian (Adjeng Nawang }
$$
Gumelar, 2016)" Sistem Diagnosa Penyakit Diabetes Mellitus Mengunakan Metode Forward Chaining" Berdasarkan hasil implementasi dan analisis sistem pada program sistem pakar untuk mendiagnosa penyakit diabetes mellitus menggunakan metode Forward Chaining berhasil di implementasikan dalam sistem pakar untuk mendiagnosa penyakit diabetes mellitus. Akan tetapi data yang dikumpulkan hanya berasal dari buku yang berjudul Mengenal Deabetes Melitus pada orang Dewasa dan Anak anak dengan solusi Herbal tanpa mendatangkan seorang pakar.

Berdasarkan hasil studi pendahuluan melalui observasi dan wawancara di Puskesmas Sandar Angin Pagar Alam, bahwa fasilitas disana belum terlalu jauh menggunakan teknologi untuk mengetahui penyakit diabetes di mana seorang pasien harus mengontrol langsung ke Dokter tanpa mengetahui tanda-tanda atau penyebab diabetes sebelumnya maka dalam mengatasi semua persoalan yang di hadapi pasien dalam hal penyakit diabetes serta untuk membantu ahli kesehatan dalam hal menyampaikan informasi tentang penyakit diabetes kepada pasien oleh karena itu pada penelitian ini akan dibuat suatu aplikasi sistem pakar yang memberikan informasi mengenai penyakit 
diabetes tipe 1 dan diabetes tipe 2, sekaligus memberikan solusi pencegahanya, yang nantinya dapat digunakan untuk mengurangi resiko terinfeksi penyakit diabetes. Implementasi sistem pakar ini dibuat dengan berbasis web agar dapat diakses dan dimanfaatkan masyarakat secara luas.

\section{METODOLOGI PENELITIAN}

\subsection{Sistem Pakar}

(Muhammad Arhami, 2005:9) mengatakan bahwa Sistem pakar (Expert System) merupakan paket perangkat lunak atau paket program komputer yang ditujukan sebagai penyedia nasihat dan sarana bantu dalam memecahkan masalah di bidang-bidang spesialisasi tertentu seperti sains, perekayasaan, pertanian, matematika, kedokteran, pendidikan dan sebagainya. Sistem pakar merupakan subset dari Artificial Intelligence. (Muhammad Arhami , 2005:3) mengatakan bahwa Sistem pakar adalah salah satu cabang dari AI yang membuat penggunaan secara luas knowledge yang khusus untuk penyelesaian masalah tingkat manusia yang pakar. Seorang pakar adalah seseorang yang mempunyai keahlian dibidang tertentu, yaitu pakar yang mempunyai knowledge atau kemampuan khusus yang orang lain tidak mengetahui atau mampu dalam bidang yang dimilikinya. Ketika sistem pakar dikembangkan pertama kali sekitar tahun 70-an, sistem pakar hanya berisi knowledge eksklusif. Namun sekarang ini istilah sistem pakar sudah digunakan untuk berbagai macam sistem yang menggunakan teknologi sistem pakar itu. Teknologi sistem pakar ini meliputi bahasa sistem pakar, program dan perangkat keras yang dirancang untuk membantu pengembangan dan pembuatan sistem pakar.

dari seorang pakar di bidang masing -masing.

\subsection{Sejarah Sistem Pakar}

Sistem pakar mulai dikembangkan pada pertengahan tahun 1960-an oleh Artifial Intelligence Corporation. Periode penelitian kecerdasan buatan ini didominasi oleh suatu keyakinan bahwa nalar yang digabung dengan komputer canggih akan menghasilkan prestasi pakar bahkan manusia super. Suatu usaha kearah ini adalah General Purpose Problem Solver (GPS) yang dikembangkan oleh Allen Newell, John Cliff Shaw, dan Hebert Alexander Simon. GPS merupakan sebuah percobaan untuk menciptakan mesin yang cerdas.

\subsection{Ciri-Ciri Sistem Pakar}

a) Pengetahuan sistem pakar merupakan suatu konsep, bukan berbentuk numeris. Hal ini dikarenakan komputer melakukan proses pengolahan data secara numerik sedangkan keahlian dari seorang pakar adalah fakta dan aturan-aturan, bukan numerik.

b) Informasi dalam sistem pakar tidak selalu lengkap, subyektif, tidak konsisten, subyek terus berubah dan tergantung pada kondisi lingkungan sehingga keputusan yang diambil bersifat tidak pasti dan tidak mutlak 
"ya" atau "tidak" akan tetapi menurut ukuran kebenaran tertentu. Oleh karean itu dibutuhkan kemampuan sistem untuk belajar secara mandiri dalam menyelesaikan masalah-masalah dengan pertimbangan khusus.

c) Kemungkinan solusi Sistem Pakar terhadap suatu permasalahan adalah bervariasi dan mempunyai banyak pilihan jawaban yang dapat diterima, semua faktor yang ditelusuri memiliki ruang masalah yang luas dan tidak pasti. Oleh karena itu diperlukan sistem yang fleksibel dalam menangani kemungkinan solusi dari berbagai permasalahan.

d) Perubahan atau pengembangan pengetahuan dalam Sistem Pakar dapat terjadi setiap saat bahkan sepanjang waktu sehingga diperlukan kemudahan dalam modifikasi sistem untuk menampung jumlah pengetahuan yang semakin besar dan semakin bervariasi.

e) Pandangan dan pendapat setiap pakar tidaklah selalu sama, yang oleh karena itu tidak ada jaminan bahwa solusi Sistem Pakar merupakan jawaban yang pasti benar. Setiap pakar akan memberikan pertimbanganpertimbangan berdasarkan faktor subyektif.

f) Keputusan merupakan bagian terpenting dari Sistem Pakar. Sistem Pakar harus memberikan solusi yang akurat berdasarkan masukan pengetahuan meskipun solusinya sulit sehingga fasilitas informasi sistem harus selalu diperlukan.Senada dengan keterangan di atas, (Muhammad Arhami, 2005:23) menerangkan sifat sistem pakar secara umum sebagai berikut:

1. Memiliki informasi yang handal, baik menampilkan langkah-langkah antara maupun dalam menjawab pertanyaan-pertanyaan tentang proses penyelesaian.

2. Mudah di modifikasi, yaitu dengan menambah atau menghapus suatu kemampuan dari basis pengetahuanya.

3. Heuristik dalam menggunakan pengetahuanya (yang sering kali tidak sempurna) untuk mendapatkan penyelesaianya.

4. Dapat digunakan dalam berbagai jenis komputer.

5. Memiliki kemampuan beradaptasi.

\subsection{Arsitektur Sistem Pakar}

(Muhammad

Arhamni, 2005:13)mengatakan bahwa Sistem pakar disusun oleh dua bagian utama, yaitu lingkungan pengembangan (development environment) dan lingkungan konsultasi (consultation environment). Lingkungan pengembangan sistem pakar digunakan untuk memasukkan pengetahuan pakar kedalam lingkungan sistem pakar, sedangkan lingkungan konsultasi digunakan oleh pengguna yang bukan pakar guna memperoleh pengetahuan pakar. 


\subsection{Fasilitas Akuisi Pengetahuan}

Muhammad Arhami $\quad$ (2005:16)
mengatakan bahwa Fasilitas Akuisi
pengetahuan adalah akumulasi, transfer dan
tranformasi keahlian dalam menyelesaikan
masalah dari sumber pengetahuan ke dalam
program komputerPengetahuan dapat
diperoleh melalui studi pustaka maupun
observasi dan bertanya langsung kepada
pakarnya. Pengetahuan dan data-data yang
terkumpul itulah yang disebut knowledge base
(basis pengetahuan).

\subsection{Basis Pengetahuan}

Muhammad arhami

(2005:15)

mengatakan bahwa Basis pengetahuan mengandung pengetahuan untuk pemahaman, formulasi dan penyelesaian masalah. Komponen sistem pakar ini disusun atas dua elemen dasar, yaitu fakta dan aturan. Fakta merupakan informasi tentang obyek dalam area permasalahan tertentu, sedangkan aturan merupakan informasi tentang cara bagaimana memperoleh fakta yang telah diketahui.

\subsection{Mesin Inferensi}

Muhammad arhami (2005:19) mengatakan bahwa Mesin Inferensi (Inference engine) merupakan otak darisistem pakar, bagian ini mengandung mekanisme fungsi berpikir dan pola-pola penalaran sistem yang digunakan oleh seorang pakar. Mesin inferensi adalah program komputer yang memberikan metologi untuk penalaran tentang informasi yang ada dalam basis pengetahuan dan dalam workplace, dan untuk memformulasikan kesimpulan.

Secara umum ada dua teknik utama yang digunakan dalam mekanisme inferensi untuk pengujian aturan, yaitu penalaran maju (forward chaining) dan penalaran mundur (backward chaining).

Pelacakan atau penalaran kebelakang (backward chaining) adalah pendekatan yang dimotori tujuan (goal-driven) (Muhammad Arhami, 2005:19). Penalaran ini juga biasa disebut penalaran dari atas ke bawah (Muhammad Arhami, 2005:116) yaitu penalaran dari level paling bawah yang dapat mendukung hipotesis, turun ke fakta level paling bawah yang dapat mendukung hipotesis. Dapat dikatakan pula dalam backward chaining menunjukkan fakta yang ada digunakan untuk mendukung hipotesis. gambaran backward chanining diperlihatkan pada gambar.

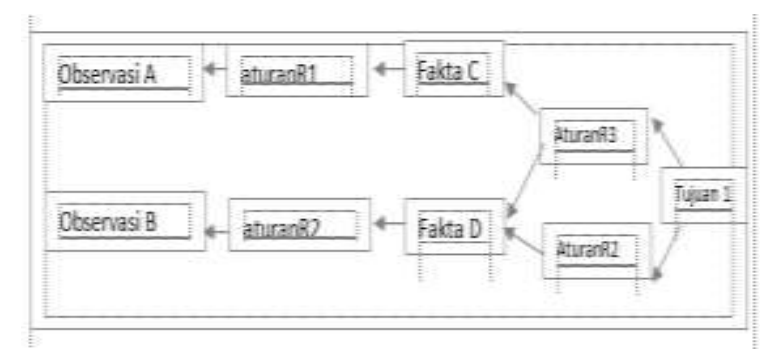

Gambar 1. Pola Backward Chaining

Pelacakan atau penalaran ke depan (forward chaining) adalah metode pencarian atau penarikan kesimpulan yang berdasarkan pada data atau fakta yang ada menuju ke kesimpulan, penelusuran dimulai dari fakta yang ada lalu bergerak maju melalui permispermis untuk menuju kesimpulan atau dapat di 
katakan bottom up reasoning. forward chaining melakukan pencarian dari suatu masalah kepada solusinya, gambarannya dapat di lihat pada gambar 2 .

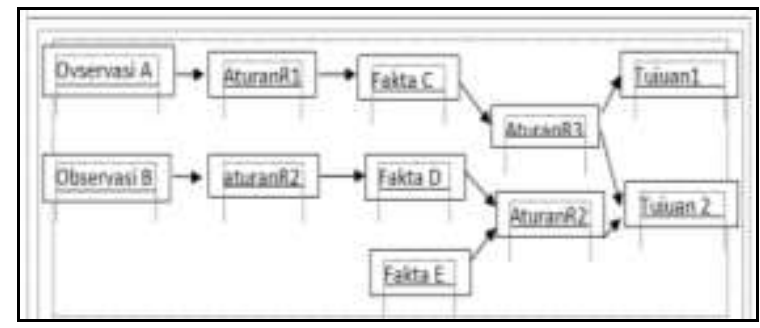

\section{Gambar 2. Pola Forward Chaining}

Dua pola pencarian di atas akan bergantung pula pada pola penelusuran yang diterapkan. Ada tiga jenis pola yang dapat digunakan yaitu depth-first search, breadhtfirst search dan best first search.

\section{a) Depth-first Search}

(Muhammad Arhamni, 2005:20) mengatakan bahwa Depth-first Search melakukan penelusuran kaidah secara mendalam dari simpul akar bergerak menurun ke tingkat dalam yang berurutan.

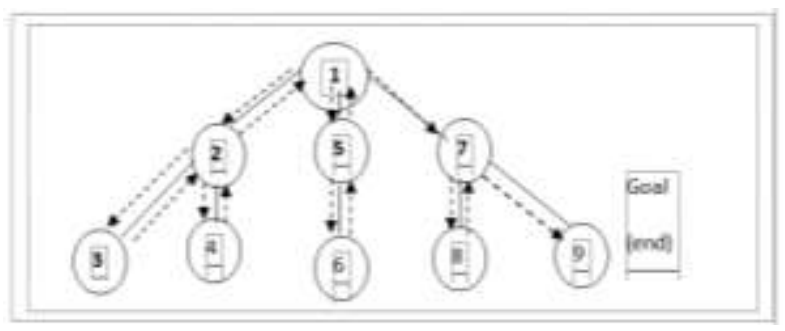

Gambar 3. Pola Penelusuran Depth-first

\section{Searc}

b) Breadht-First Search

Muhammad Arhami

(2005:20)

mengatakan bahwa breadht-first search begerak darisimpul akar, simpul yang ada pada setiap tingkat diuji sebelum pindah ketingkat selanjutnya.

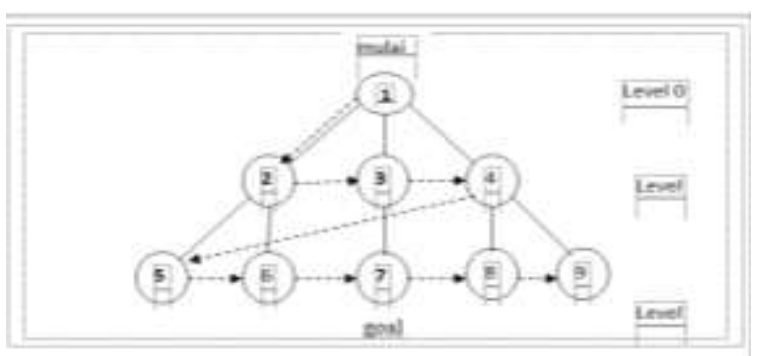

\section{Gambar 4. Pola Penelusuran breadht-first search}

c) Best First Search

Muhamammad Arhami (2005:20) mengatakan bahwa Best first search adalah penelusuran yang menggunakan pengetahuan akan suatu masalah untuk melakukan panduan pencarian ke arah node tempat dimana solosi berada. Pencarian jenis ini dikenal juga sebagai heuristik. Dapat dikatakan pula best first search bekerja berdasarkan kombinasi kedua metode sebelumya.

\subsection{Antar Muka Pengguna}

(Muhamma

Arhammni, 2005:14)mengatakan User interface (antarmuka pengguna) merupakan mekanisme yang digunakan oleh pengguna dan sistem pakar untuk berkomunikasi. Antarmuka menerima informasi dari pemakai dan mengubahnya kedalam bentuk yang dapat diterima oleh sistem. Selain itu antar muka menerima informasi dari sistem dan meyajikannya kedalam bentuk yang dapat di mengerti oleh pemakai. Pada bagian ini terjadi dialog antara program dan pemakai, yang memungkinkan sistem pakar menerima instruksi dan informasi (input) dari pemakai, juga memberikan informasi (Output) kepada pemakai. 


\subsection{Representasi Pengetahuan}

Representasi pengetahuan merupakan kombinasi sistem berdasarkan dua elemen, yaitu struktur data dan penafsiran prosedur untuk digunakan pengetahuan dalam menyimpan struktur data. Dalam sistem pakar pengetahuan yang telah di uraikan, direpresentasikan ke dalam bentuk yang dapat diperoses oleh komputer. Menurut (Muhammad Arhamni, 2005:28) terdapat empat teknik yang telah dibuktikan efektif untuk representasi pengetahuan, yaitu jaringan semantik (semantic network), frame dan script, serta aturan produksi.

\subsection{Jaringan Semantik (Semantic Network)}

Jaringan semantik merupakan teknik representasi AI yang digunakan untuk informasi yang proporsional. Jaringan semantik kadang disebut juga sebagai jaringan proposional. Seperti yang telah di diskusikan sebelumnya, propotion adalah suatu pernyataan yang dapat bernilai benar atau salah, seperti pernyataan "semua kucing adalah mamalia" dan "sebuah segitiga mempunyai tiga sisi”. Proposisi merupakan bentuk pengetahuan deklaratif karena menyatakan fakta. Dalam matematika, istilah jaringan semantik merupakan label atau graph berarah.

Struktur dari jaringan semantik ditujukan secara grafik yang terdiri dari simpul (node) dan busur (arc) yang menghubungkanya. Simpul menyatakan objek, konsep atau situasi, sedangkan busur digunakan sebagai links atau edge yang menyatakan hubungan (relationlship) antar simpul. Contoh jaringan semantik ditunjukan pada gambar .

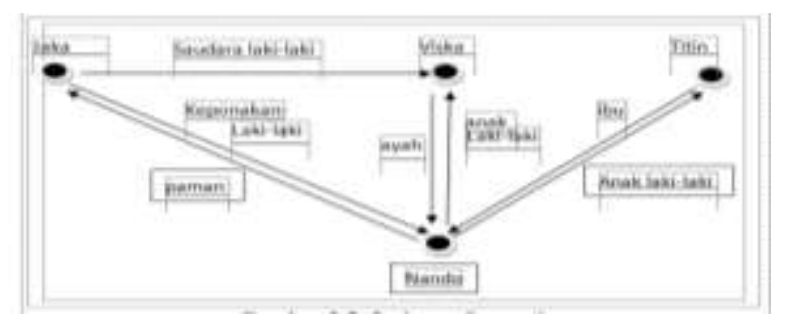

Gambar 5. Jaringan Semantik

\subsection{Metode Pengumpulan Data}

Dalam pengumpulan data yang diperlukan untuk penelitian ini, diantaranya adalah Metode Studi Pustaka, Metode Observasi, Metode Wawancara dan Dokumentasi. Diadopsi dari :

a) Studi pustaka

Metode ini dilaksanakan dengan melakukan studi kepustakaan melakukan membaca buku-buku maupun artikelartikel yang dapat mendukung proses penyelesaian pengerjaan penelitian ini.

b) Observasi

Yaitu pengumpulan data yang dilakukan dengan pengamatan secara langsung guna mendapatkan data-data dan fakta yang diperlukan.

c) Metode Wawancara

Metode wawancara merupakan suatuh teknik pengumplan data/fakta yang bisa dipertanggung jawabkan kebenaranya, kerena pada metode ini peneliti bertanya langsung pada pakar penyakit diabetes di puskesmas Sandar Angin kota Pagaralam. 
d) Dokumentasi

Teknik pengumpulan data ini juga dilakukan oleh penulis, guna untuk memenuhi kebutuhan data bagi penulis.

\subsection{Analisa sistem yang sedang berjalan}

Berdasarkan hasil dari observasi saat ini proses pelayanan konsultasi yang berjalan ditentukan oleh dokter dengan pasien masih harus bertemu pada puskesmas sandar angin Pagaralam ditunjukan pada gambar dibawah ini.

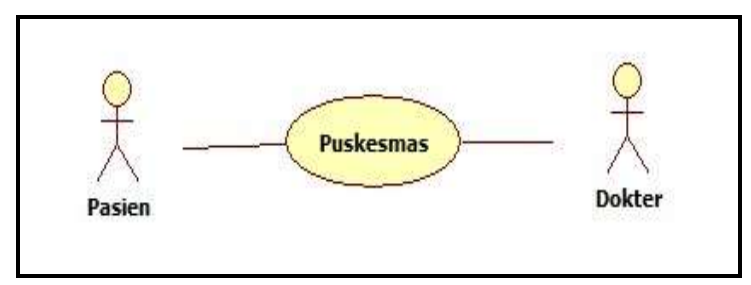

Gambar 6. Alur sistem yang sedang berjalan

Pada gambar diatas Pasien datang ke Puskesmas Sandar Angin Pagar Alam untuk memeriksa penyakit diabetes yang diderita kemudian pasien menemui dokter untuk konsultasi.

\subsection{Analisa Sistem Yang Diusulkan}

Dengan adanya proses pelayanan konsultasi yang sedang berjalan ditentukan oleh dokter dengan pasien masih harus bertemu, maka dibentuklah rancangan sistem yang baru, dengan ini diharapkan dapat memberikan pelayanan yang optimal sehingga dapat memberikan manfaat informasi yang berguna bagi masyarakat terhadap penyakit, gejala diabetes dengan menggunakan program PHP/My Sql pada Puskesmas Sandar Angin
Pagar Alam. Proses konsultasi yang baru diusulkan oleh penulis yaitu dengan cara mengubah proses pelayanan konsultasi yang berjalan ditentukan oleh dokter dengan pasien yang masih harus bertemu dengan sistem pakar berbasis Web. Dengan adanya sistem pakar ini dapat mempermudah masyarakat untuk konsultasi penyakit diabetes tanpa harus menemui dokter secara langsung. Adapun contoh dari sistem baru yang diusulkan oleh penulis sebagai berikut :

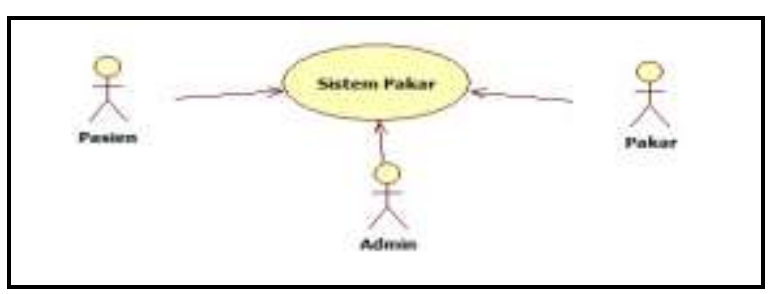

Gambar 17. Alur sistem yang diusulkan

\subsection{Use Case Diagram}

Use case Diagram menggambarkan fungsionalitas yang diharapkan dari sebuah sistem. Yang ditekankan adalah " apa " yang diperbuat sistem dan bukan " bagaimana “ sebuah Use case mempresentasikan sebuah interaksi antara aktor dengan sistem. pada use case ini admin diharuskan $\log$ in dan akan dihadapkan pada beberapa pilihan seperti validasi data user, data penyakit, gejala, hasil diagnosa, informasi, profil. Dan untuk user Setelah $\log$ in akan dihadapkan pada halaman konsultasi saja. 


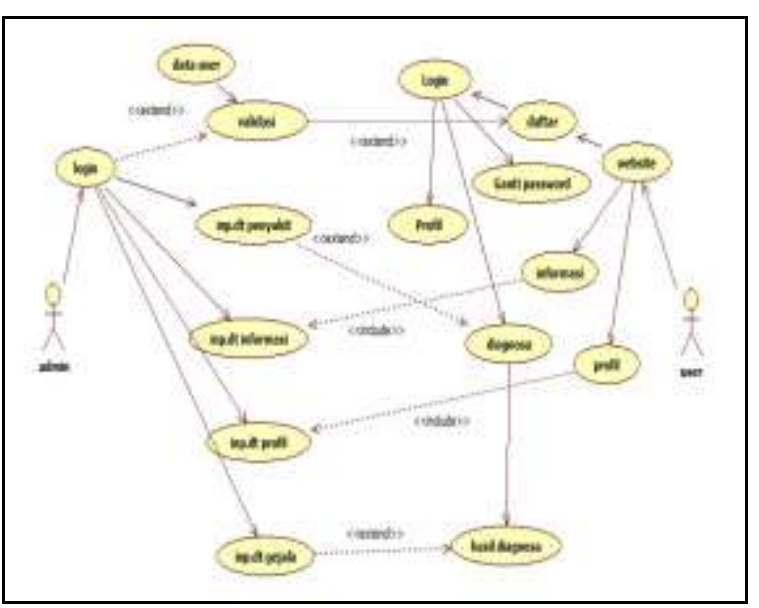

Gambar 18.Use Case Diagram

\subsection{Class Diagram}

Pada sistem pakar ini class diagram yang digunakan dapat dilihat pada gambar dibawah ini.

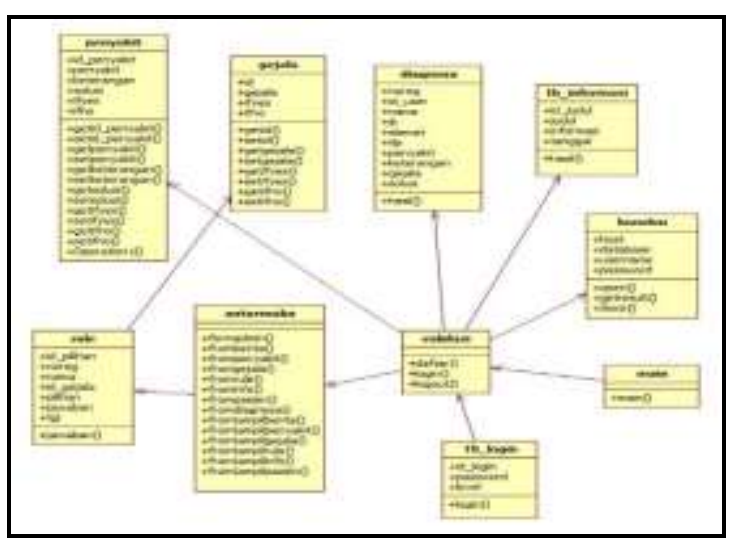

Gambar 19. Class Diagram

\subsection{Penyusunan Basis Data}

Untuk sistem ini, digunakan database MySQL dengan menggunakan 6 tabel, yaitu tabel login, tabel master penyakit, tabel master gejala, tabel diagnosa tabel informasi, dan tabel rule. untuk perancangan data base sistem ini dapat dilihat pada tabel-tabel berikut :

\section{a. Tabel Login}

Nama tabel : Tb_login
Fungsi tabel ini adalah untuk mengelola serta mengimputkan semua data. Tabel ini terdiri dari fielda dmin, nama, level.

Tabel 1. Tabel Login

\begin{tabular}{lllll}
$\mathrm{N}$ & Field & $\begin{array}{l}\text { Tipe } \\
\mathrm{d}\end{array}$ & $\begin{array}{l}\text { Panjan } \\
\mathrm{g}\end{array}$ & $\begin{array}{l}\text { Keteranga } \\
\mathrm{n}\end{array}$ \\
\hline 1 & Id_login & $\begin{array}{l}\text { Varcha } \\
r\end{array}$ & 10 & $\begin{array}{l}\text { Primary } \\
\text { key* }\end{array}$ \\
\hline 2 & $\begin{array}{l}\text { Passwor } \\
\mathrm{d}\end{array}$ & Int & 12 & Kode \\
\hline 3 & Level & $\begin{array}{l}\text { Varcha } \\
r\end{array}$ & 15 & - \\
& & &
\end{tabular}

\section{b. Tabel Penyakit}

\section{Nama tabel : Tb_Penyakit}

Fungsi dari tabel ini adalah menginputkan dan menyimpan data master Penyakit. Tabel ini terdiri darifield. Id penyakit, penyakit, keterangan, solusi, Ifyes dan Ifno.

Tabel 2. Tabel Penyakit

\begin{tabular}{lllll}
\hline No & Field & $\begin{array}{l}\text { Tipe } \\
\text { data }\end{array}$ & $\begin{array}{l}\text { Panjan } \\
\mathrm{g}\end{array}$ & $\begin{array}{l}\text { Keterang } \\
\text { an }\end{array}$ \\
\hline 1 & $\begin{array}{l}\text { Id_Peny } \\
\text { akit }\end{array}$ & Int & 10 & $\begin{array}{l}\text { Primary } \\
\text { key* }\end{array}$ \\
\hline 2 & Penyakit & $\begin{array}{l}\text { Varch } \\
\text { ar }\end{array}$ & 20 & Penyakit \\
\hline 3 & $\begin{array}{l}\text { Keterang } \\
\text { an }\end{array}$ & Int & 15 & - \\
\hline 4 & Solusi & Int & 15 & - \\
\hline 5 & Ifyes & $\begin{array}{l}\text { Varch } \\
\text { ar }\end{array}$ & 10 & - \\
\hline 6 & Ifno & $\begin{array}{l}\text { Varch } \\
\text { ar }\end{array}$ & 110 & - \\
\hline
\end{tabular}

\section{c. Tabel Gejala}

Nama tabel : Tb_Gejala

Fungsi tabel ini adalah menginputkan data master gejala dan menyimpan data master gejala. Tabel ini terdiri dari field. Id gejala, nama gejala, ifyes dan ifno.

Tabel 3. Tabel Gejala.

\begin{tabular}{lllll} 
No & Field & $\begin{array}{l}\text { Tipe } \\
\text { data }\end{array}$ & Panjang & $\begin{array}{l}\text { Keteran } \\
\text { gan }\end{array}$ \\
\hline 1 & $\begin{array}{l}\text { Id_Gej } \\
\text { ala }\end{array}$ & Int & 9 & $\begin{array}{l}\text { Primary } \\
\text { key* }\end{array}$ \\
\hline 2 & Gejala & $\begin{array}{l}\text { Varcha } \\
r\end{array}$ & 120 & Gejala \\
\hline 3 & ifYes & Varcha & 10 & - \\
\hline
\end{tabular}




\begin{tabular}{lllll}
\hline \multicolumn{5}{c}{$r$} \\
\hline 4 & ifNo & Varcha & 10 & -
\end{tabular}

\section{d. Tabel Diagnosa}

Nama tabel : Tb_Diagnosa

Tabel ini berfungsi untuk menginput data diagnosa dan menyimpannya. Tabel ini terdiri dari field noreg, id user, nama, jk, alamat, tlpn, penyakit, keterangan, id master gejala, dan solusi.

Tabel 4. Tabel Diagnosa

\begin{tabular}{lllll}
$\begin{array}{l}\mathrm{N} \\
\mathrm{o}\end{array}$ & Field & $\begin{array}{l}\text { Tipe } \\
\text { data }\end{array}$ & $\begin{array}{l}\text { Panjan } \\
\mathrm{g}\end{array}$ & $\begin{array}{l}\text { Keterang } \\
\text { an }\end{array}$ \\
\hline 1 & Noreg & $\begin{array}{l}\text { Varch } \\
\text { ar }\end{array}$ & 10 & Kode \\
\hline 2 & id_user & Int & 7 & $\begin{array}{l}\text { Primary } \\
\text { key* }\end{array}$ \\
\hline 3 & Nama & $\begin{array}{l}\text { Varch } \\
\text { ar }\end{array}$ & 50 & - \\
\hline 4 & Jk & Varch & 10 & -
\end{tabular}

\begin{tabular}{lllll}
\multicolumn{5}{c}{ ar } \\
\hline 5 & Alamat & Text & - & - \\
\hline 6 & Tlp & Varch & 15 & -
\end{tabular}

\begin{tabular}{lllll}
\multicolumn{5}{c}{ ar } \\
\hline 7 & Penyakit & Text & - & - \\
\hline 8 & $\begin{array}{l}\text { Keterang } \\
\text { an }\end{array}$ & Text & - & - \\
\hline 9 & Gejala & Text & - & - \\
\hline 10 & Solusi & Text & - & -
\end{tabular}

\section{e. Tabel Informasi}

Nama tabel : Tb_Informasi

Fungsi dari tabel ini adalah mengimputkan dan menyimpan data informasi tabel ini terdri dari field $I d$, judul, informasi dan tanggal.

Tabel 5 Tabel Informasi

\begin{tabular}{|c|c|c|c|c|}
\hline No & Field & $\begin{array}{l}\text { Type } \\
\text { data }\end{array}$ & $\begin{array}{l}\text { Panjan } \\
\mathrm{g}\end{array}$ & $\begin{array}{l}\text { Keteranga } \\
\mathrm{n}\end{array}$ \\
\hline 1 & ${ }_{l}^{I d \_j u d u}$ & Int & 10 & $\begin{array}{l}\text { Primary } \\
\text { key* }\end{array}$ \\
\hline 2 & Judul & $\begin{array}{l}\text { Varcha } \\
r\end{array}$ & 50 & Penyakit \\
\hline 3 & $\begin{array}{l}\text { Inform } \\
\text { asi }\end{array}$ & Text & - & Isi \\
\hline 4 & $\begin{array}{l}\text { Tangga } \\
1\end{array}$ & Date & - & \\
\hline
\end{tabular}

\section{f. Tabel Rule}

\section{Nama tabel : Tb_Rule}

Fungsi tabel ini adalah menginputkan dan menyimpan. Tabel ini terdiri dari field, id pilihan (primary key), noreg, nama, id_gejala, pilihan, jawaban dan tgl.

Tabel 6.Tabel Rule

\begin{tabular}{|c|c|c|c|c|}
\hline No & Field & $\begin{array}{l}\text { Tipe } \\
\text { data }\end{array}$ & $\begin{array}{l}\text { Panjan } \\
\text { g }\end{array}$ & $\begin{array}{c}\text { Keterang } \\
\text { an }\end{array}$ \\
\hline 1 & $\begin{array}{l}I d \_ \text {pili } \\
\text { han }\end{array}$ & Int & 5 & $\begin{array}{l}\text { Primary } \\
\text { key* }\end{array}$ \\
\hline 2 & Noreg & $\begin{array}{l}\text { Varch } \\
\text { ar }\end{array}$ & 10 & Kode \\
\hline 3 & Nama & $\begin{array}{l}\text { Varch } \\
\text { ar }\end{array}$ & 50 & - \\
\hline 4 & $\begin{array}{l}\text { Id_gej } \\
\text { ala }\end{array}$ & $\begin{array}{l}\text { Varch } \\
\text { ar }\end{array}$ & 5 & - \\
\hline 5 & $\begin{array}{l}\text { Piliha } \\
\mathrm{n}\end{array}$ & $\begin{array}{l}\text { Varch } \\
\text { ar }\end{array}$ & 10 & - \\
\hline 6 & $\begin{array}{l}\text { Jawab } \\
\text { an }\end{array}$ & $\begin{array}{l}\text { Varch } \\
\text { ar }\end{array}$ & 10 & - \\
\hline 7 & Tgl & date & - & - \\
\hline
\end{tabular}

\section{HASIL \& PEMBAHASAN}

\subsection{Pembahasan Tampilan Halaman utama}

Pada menu home sistem pakar ini memiliki beberapa menu diantaranya menu home, menu profil yang yang berisi tentang penjelasan penyakit diabetes, menu daftar untuk menginputkan data pengguna, dan menu $\log$ in. untuk lebih detail lagi akan dibahas dengan gambar dibawah ini:

\subsubsection{Menu Home}

Menuini merupakan halaman utama ketika sistem pakar ini diakses, pada menu ini ada beberapa menu pilihan seperti menu Home, menu Profil, Menu Informasi, Menu Daftar dan Menu Log in. 


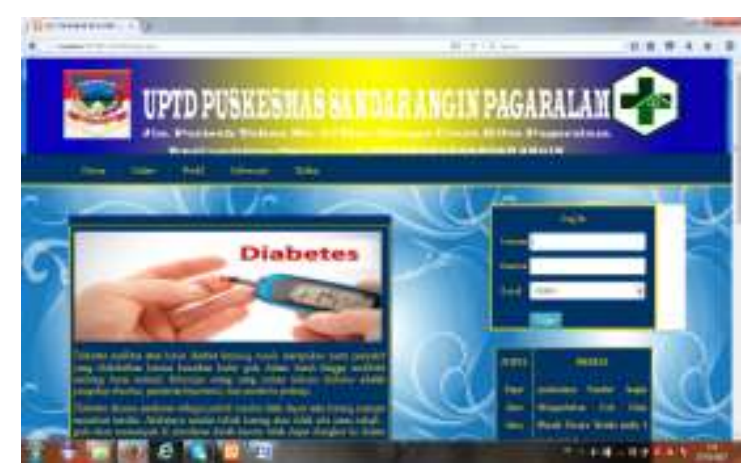

Gambar 20. Menu Home

\subsubsection{Menu galeri}

Menu ini adalah menu galeri, dimana pada menu ini berisi tentang fhoto-fhoto penyakit diabetes. Berikut gambar tampilannya.

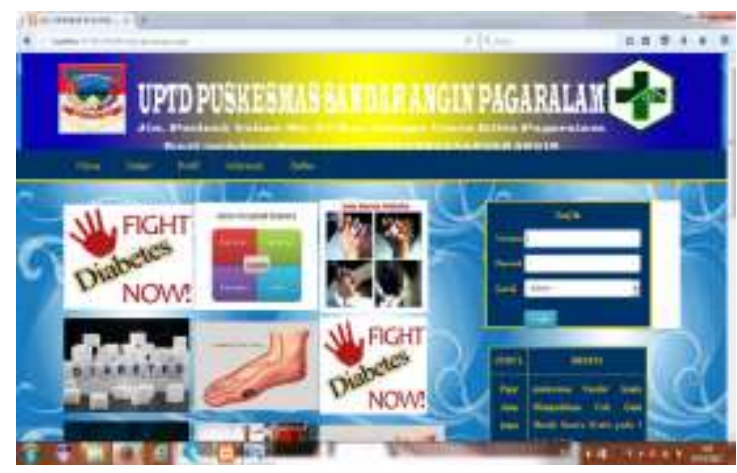

\section{Gambar 21. Menu Galeri}

\subsubsection{Menu Profil}

Menu ini adalah menu profil, dimana pada menu ini berisi tentang sejarah dan visi misi puskesmas sandar angin kota pagar alam. Berikut gambar tampilannya.

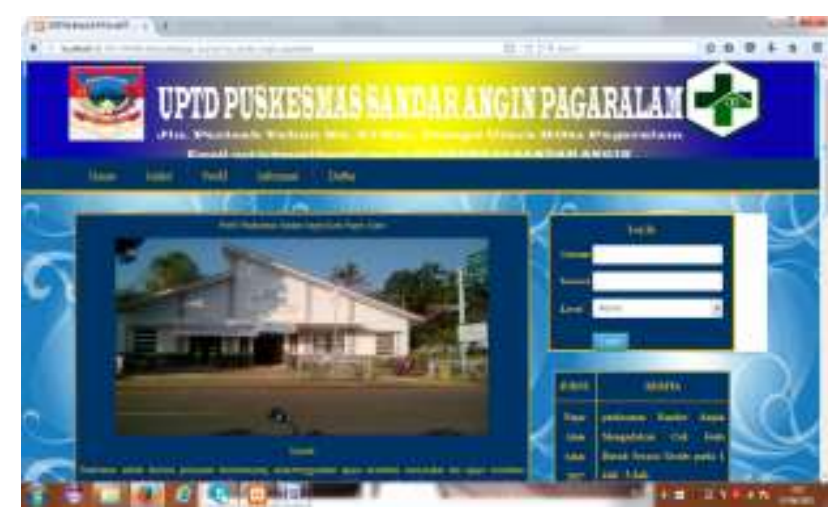

\section{Gambar 22. Menu Profil}

\subsubsection{Menu informasi}

Menu ini berisi tentang informasi gejala serta jenis penyakit diabetes. Berikut adalah gambar tampilannya.

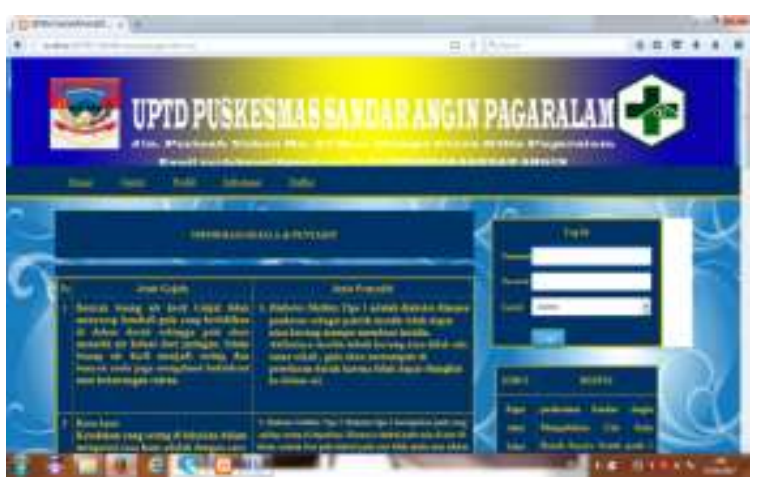

Gambar 23. Menu Informasi

\subsubsection{Menu Daftar}

Menu daftar berfungsi untuk mendapatkan username dan password bagi user yang log in sebagai pengguna, setelah mengisi semua identitas yang harus dipenuhi secara benar. Berikut gambar tampilannya. 


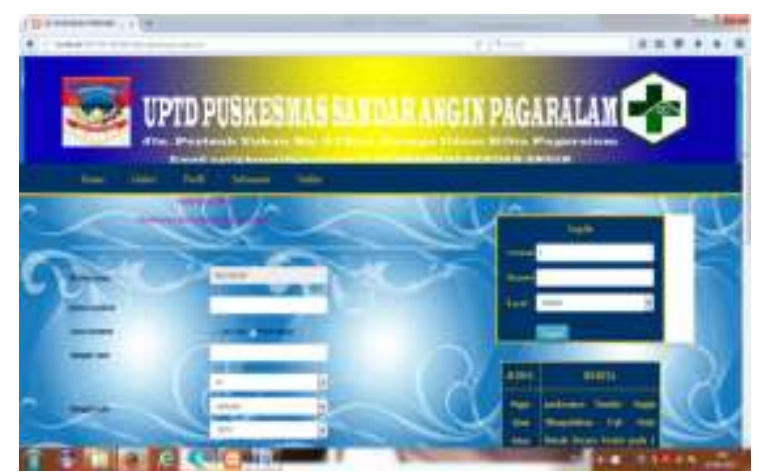

Gambar 24. Menu Daftar

\subsubsection{Menu Log In}

Menu log in berfungsi untuk user baik sebagai $a d m i n$ ataupun sebagai pengguna untuk masuk ke sistem pakar ini. Berikut gambar tampilannya.

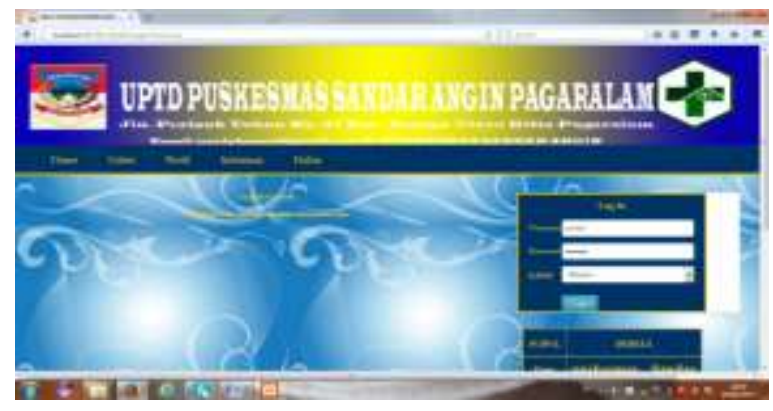

Gambar 25. menu $\log$ in

\subsubsection{Halaman Pengguna (User)}

Di halaman ini pengguna yang telah

$\log$ in dapat melakukan beberapa aktivitas seperti melihat profil, melakukan proses pendiagnosaan, dan bisa juga untuk mengganti password dan menu keluar.
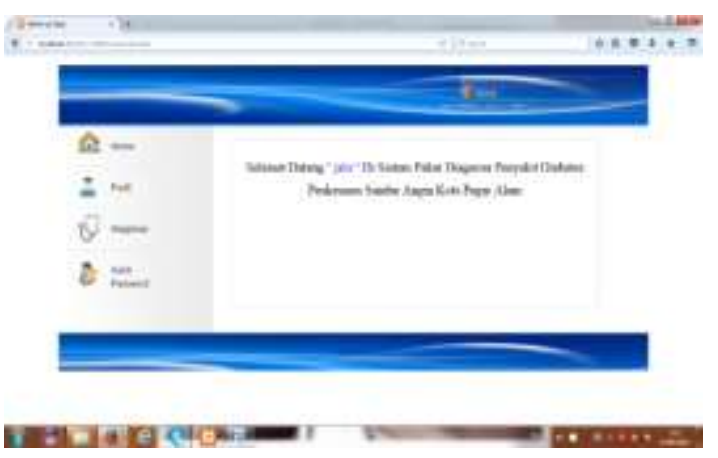

Gambar 26. Halaman pengguna (user)

\subsubsection{Halaman Profil Pengguna}

Halaman profil pengguna adalah sebuah halaman dimana pengguna dapat melihat profilnya, halaman ini berguna untuk mengecek identitas pengguna.

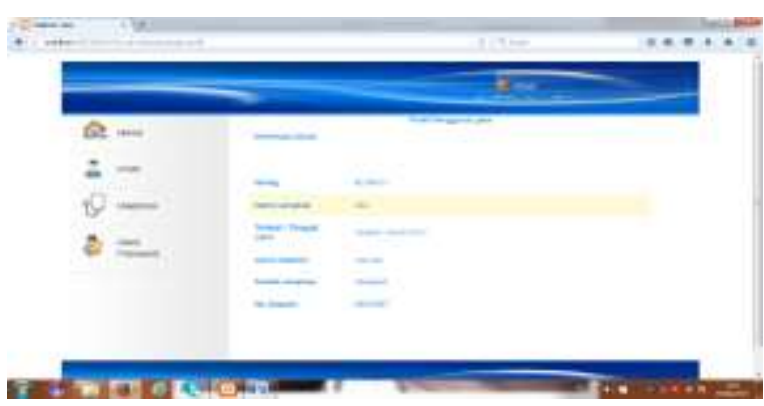

Gambar 31. Profil pengguna

\subsubsection{Halaman Diagnosa Pengguna}

Halaman keluhan pengguna adalah sebuah halaman dimana pengguna dapat melakukan proses pendiagnosaan. Berikut gambar tampilannya.

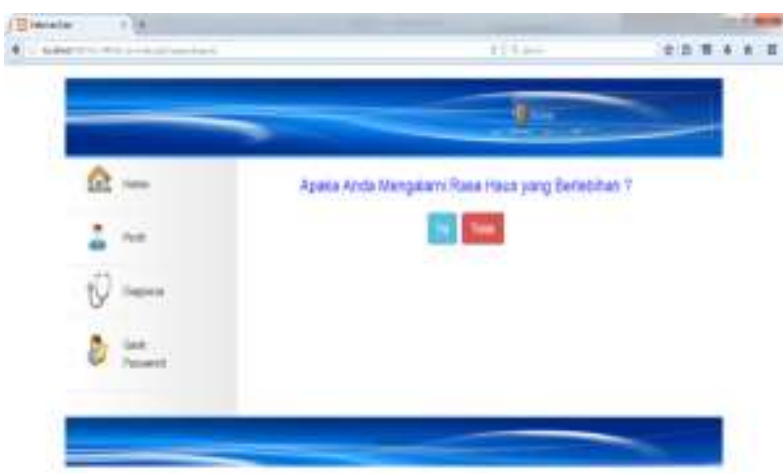

\section{Gambar 32.Diagnosa Keluhan Pengguna}

\subsubsection{OutputHasil Diagnosa Penyakit Diabetes Tipe 1 \\ Output hasil diagnosa diabetes tipe} 1, hardcopy dari hasil diagnosa diabetes tipe 1 . Berikut gambar output hasil diagnosa. 


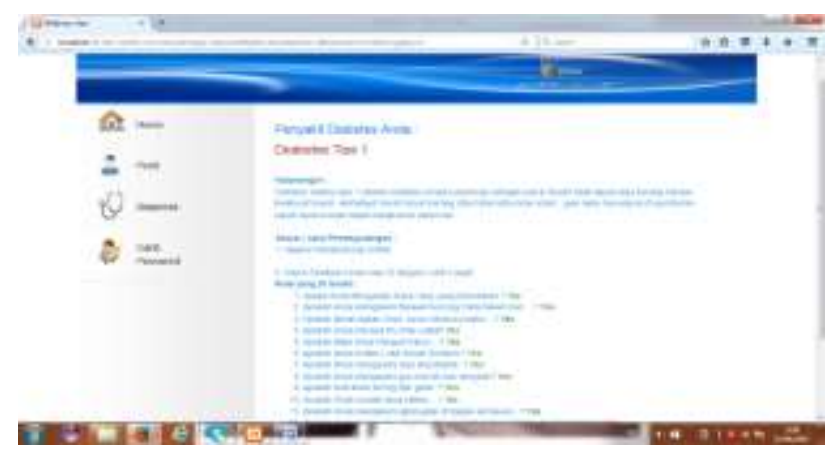

Gambar 33.OutputHasil Diagnosa Penyakit Diabetes Tipe 1

\subsubsection{Output Hasil Diagnosa Diabetes}

Tipe 2

Output hasil diagnosa diabetes tipe 2, hardcopy dari hasil diagnosa diabetes tipe 2. Berikut gambar output hasil diagnosa.

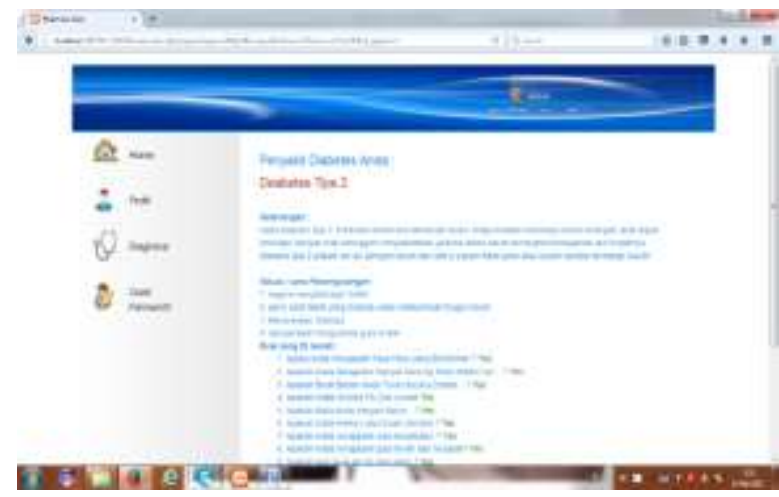

Gambar 34. OutputHasil Diagnosa Diabetes Tipe 2

\subsubsection{Output Hasil Diagnosa Negatif Diabetes}

Output hasil diagnosa negatif diabetes, hardcopy dari hasil negatif diabetes. Berikut gambar output hasil diagnosa.

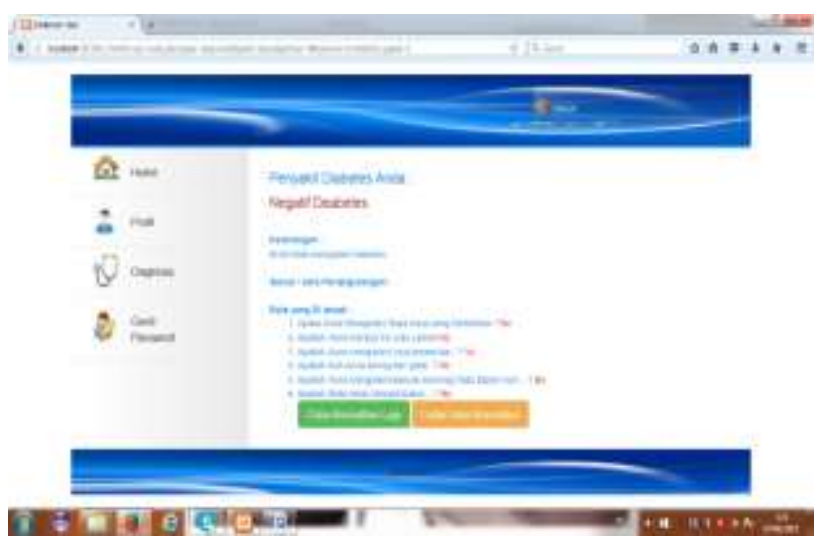

Gambar 35. OutputHasil Diagnosa Negatif

Diabetes

\section{DAFTAR PUSTAKA}

Arhami Muhammad. 2005. Konsep Dasar Sistem Pakar. Andi : Yogyakarta

Kurniawan Budi. 2008. Aplikasi sistem pakar berbasis web untuk diagnosa penyakit gigi dan mulut. ISSN : 1907-5022.

Kusnadi Adhi. 2013. Perancangan aplikasi sistem pakar untuk mendiagnosa penyakit pada manusia. ISSN : 20854552.

Mastering CMS Programming with PHP \& MySQL. 2011. Andi Offsett. Yogyakarta.

Munawar. 2005. Permodelan Visual Dengan $U M L$. Graha Ilmu. Yogyakarta.

Noor Juliansyah. 2011. Metodologi Penelitian. Kencana prenada Media Group. Jakarta.

Pressman Roger. 2012. Rekayasa Perangkat Lunak Pendekatan Praktisi. Andi. Yogyakarta.

Priyo Utomo Eko. 2013. Mobile Programming HTML, CSS3, jQUERRY Mobile. Andi Offset. Yogyakarta.

Sutojo.T, Mulyanto Edy, Suhartono Vincent. 2011. Kecerdasan Buatan. Andi Offset. Yogyakarta.

Y.Laban.Yoannes. 2008. TBC Penyakit \& cara pencegahannya. Kanisius : Yogyakarta 
Idi Jangcik 